\title{
Interaction of the Escherichia coli Replication Terminator Protein (Tus) with DNA: A Model Derived from DNA-Binding Studies of Mutant Proteins by Surface Plasmon Resonance ${ }^{\dagger}$
}

\author{
Cameron Neylon, Susan E. Brown, Andrew V. Kralicek, Caroline S. Miles, Christopher A. Love, and \\ Nicholas E. Dixon* \\ Research School of Chemistry, Australian National University, Canberra, ACT 0200, Australia
}

Received May 24, 2000; Revised Manuscript Received July 18, 2000

\begin{abstract}
The Escherichia coli replication terminator protein (Tus) binds tightly and specifically to termination sites such as TerB in order to halt DNA replication. To better understand the process of Tus-TerB interaction, an assay based on surface plasmon resonance was developed to allow the determination of the equilibrium dissociation constant of the complex $\left(K_{\mathrm{D}}\right)$ and association and dissocation rate constants for the interaction between Tus and various DNA sequences, including TerB, single-stranded DNA, and two nonspecific sequences that had no relationship to TerB. The effects of factors such as the $\mathrm{KCl}$ concentration, the orientation and length of the DNA, and the presence of a single-stranded tail on the binding were also examined. The $K_{\mathrm{D}}$ measured for the binding of wild type and $\mathrm{His}_{6}$-Tus to TerB was $0.5 \mathrm{nM}$ in $250 \mathrm{mM} \mathrm{KCl}$. Four variants of Tus containing single-residue mutations were assayed for binding to TerB and the nonspecific sequences. Three of these substitutions (K89A, R198A, and Q250A) increased $K_{\mathrm{D}}$ by $200-300$-fold, whereas the A173T substitution increased $K_{\mathrm{D}}$ by 4000 -fold. Only the R198A substitution had a significant effect on binding to the nonspecific sequences. The kinetic and thermodynamic data suggest a model for Tus binding to TerB which involves an ordered series of events that include structural changes in the protein.
\end{abstract}

The DNA replication termination protein Tus blocks the progress of the replisome in the final stages of chromosomal replication in Escherichia coli and related bacterial species $(1-6)$. The Tus protein binds as a monomer to Ter sites situated in the terminus region of the bacterial chromosome in such a way as to form a replication fork trap $(7,8)$. The progress of a fork is halted when traveling in one direction (from the nonpermissive face of the complex) but not the other (the permissive face). Replication forks traveling in both directions are therefore able to enter the terminus region but not leave it. The Tus-TerB interaction is one of the strongest among protein-ligand interactions and is the strongest known DNA - protein interaction involving a monomeric DNA-binding protein. The native Tus protein binds to the $\operatorname{Ter} B$ site, for example, with an equilibrium dissociation constant $\left(K_{\mathrm{D}}\right)$ of $3.4 \times 10^{-13} \mathrm{M}$ in $150 \mathrm{mM}$ potassium glutamate, $\mathrm{pH} 7.5$ (9).

Our aim is to understand the molecular basis of the interaction of Tus with Ter DNA and especially to dissect the series of events that lead to sequence-specific DNA binding. In doing so, we expect to shed some light on the mechanism of replication termination and, in particular, on the polarity of the termination process. There is some controversy over whether Tus blocks the movement of the

$\dagger$ This work was supported in part by an Australian Postgraduate Research Award (to C.N.) and an Australian Research Council Australian Postdoctoral Fellowship (to S.E.B.).

* To whom correspendence should be addressed. Tel: +61-2-6249 4391. Fax: +61-2-6249 0750. E-mail: dixon@rsc.anu.edu.au. replication fork merely by acting as a clamp that prevents strand separation by the replicative helicase DnaB or whether specific interactions between Tus and some component of the replisome, probably DnaB, are also involved (8). Certainly, the Tus-Ter complex is capable of blocking the action of the DnaB, Rep, and SV40 helicases in a polar manner in assays where the action of the helicase is coupled to DNA replication $(7,10-12)$ and of a range of other helicases in other in vitro reactions $(7,13-17)$. With a clamp mechanism, simple thermodynamic arguments alone cannot explain the polarity of termination, so kinetic (or dynamic) arguments must be invoked. To understand better the mechanism of Tus-Ter binding, we have used surface plasmon resonance to develop a straightforward quantitative DNA-binding assay and have characterized the effect of substitution of important residues involved in sequencespecific contacts between Tus and Ter DNA sites.

To facilitate this study, we first constructed new highly enriched sources of Tus and variants of it by insertion of the tus gene into new expression vectors and developed a rapid procedure for purification of Tus in large quantities. That work is reported briefly in this paper.

The crystal structure of the Tus-Ter complex (18) indicates that the core DNA-binding domain of the protein consists of two pairs of antiparallel $\beta$-strands that lie in the major groove of the DNA. Kamada et al. (18) identified 14 residues that make sequence-specific contacts to the $\mathrm{Ter}$ DNA. Ten of these lie within the core DNA-binding domain and four lie outside it. Of these latter residues, K89 and R198 
are both at or near the nonpermissive face of the Tus-Ter complex (i.e., the end that blocks the passage of the replisome), make most of the sequence-specific contacts to this end of the Ter sequence, and are thus of interest in investigating fork arrest. The other two residues from outside the core binding domain (Q250 and Q252) also make sequence-specific contacts to the Ter DNA but do so at the permissive face of the complex. As a first step in investigating the overall DNA-binding process, we examined the effect of altering three of these outlying residues (R198 in the C-domain and K89 and Q250 in the N-domain) and one in the core binding domain (A173). Mutant tus genes were constructed in which the codons for K89, R198, and Q250 were converted to alanine codons, and A173 was converted to threonine. Residue Q252 was not altered as this would remove a salt bridge between it and K175, and it was assumed that this would destabilize the core binding domain. The A173T variant is well characterized $(19,20)$ and provides a means of comparing the results with those published previously.

Surface plasmon resonance can be exploited to allow the monitoring of biomolecular interactions in real time by measuring refractive index changes at a surface (21). To use this technique to study the interaction of Tus variants with Ter DNA, biotin-labeled oligonucleotides were immobilized on a streptavidin-coated surface. Wild-type and variant Tus proteins were allowed to flow over the immobilized DNA, and the interaction of the proteins with it were observed. Equilibrium dissociation constants $\left(K_{\mathrm{D}}\right)$ and association $\left(k_{\mathrm{a}}\right)$ and dissociation $\left(k_{\mathrm{d}}\right)$ rate constants were measured, and the effect of salt concentration as well as DNA orientation and length was examined. The results confirm that Tus binds with very high affinity to $\operatorname{Ter} B$ but also indicate that Tus can bind nonspecifically to both ss-DNA ${ }^{1}$ and ds-DNA that does not resemble TerB. The large effect of salt concentration on the association kinetics is consistent with the proposition that a conformational change is an important part of the binding process. Finally, the complexes of TerB with Tus variants all have higher dissociation constants than those observed for the wild-type Tus-TerB complex, and the trends observed suggest that the $\mathrm{N}$ - and $\mathrm{C}$-terminal domains of Tus have very different roles in binding to TerB. On the basis of these and other data, we propose that DNA binding involves sequential ordered structural changes in Tus (i.e., a zipper model), which might also help to explain the polarity of replication fork arrest by the complex.

\section{EXPERIMENTAL PROCEDURES}

Reagents, Plasmids, and General Methods. Methods for DNA manipulation were generally as described (22). Oligonucleotides, some of which (as specified) were modified at the $5^{\prime}$ end by a biotin residue followed by a 10-mer abasic poly(deoxyribose $5^{\prime}$-phosphate) spacer, were from GeneWorks (Adelaide, Australia). Vent DNA polymerase (New England Biolabs) was used in the supplied buffer for PCR. The plasmid pTH311 (9), used as source of the tus gene, was a gift from Dr. Peter Keumpel. Plasmid vectors

\footnotetext{
${ }^{1}$ Abbreviations: DTT, dithiothreitol; ds-DNA, double-stranded DNA; IPTG, isopropyl $\beta$-D-thiogalactopyranoside; RU, response units (BIACORE); ss-DNA, single-stranded DNA; Tus, Escherichia coli replication terminator protein (Swiss-Prot, P16525; PDB, 1ECR).
}

pMTL22P (23), pET3c (24), and pND706 (25) have been described. Plasmid pCL477, a derivative of vector pCL476 which directs overproduction of Met-His ${ }_{6}$-tagged M13 gene II protein, was as described (25). Plasmids were routinely selected and maintained in E. coli host strain AN1459 (26). Strain BL21(DE3) (27) was used for overexpression of tus in derivatives of pET3c. Bacteria were grown in LB medium supplemented with $25 \mathrm{mg} / \mathrm{L}$ thymine and $50 \mathrm{mg} / \mathrm{L}$ ampicillin. DNA sequencing reaction mixtures were prepared with the ABI Prism Big-Dye terminator kit (Perkin-Elmer), using vector primers 9 and 10 (26) for derivatives of pND706, PET1 (5'-CTATAGGGAGACCACAAC), PET2 (5'-CTTTCGGGCTTTGTTAGC), and primer 45 (5'-CGATGCGTCCGGCGTAG) for derivatives of pET3c, as well as primers SP1 (5'-GGTCGATAACCTTTCGC) and SP2 (5'-GGTCGATAACCTTTCGC) that are complementary to sequences within tus.

T7 Promoter Vectors pETMCSI, pETMCSII, and pETMCSIII. For construction of modified bacteriophage T7 promoter vectors, the EcoRI site in pET3c was first removed by its linearization with this enzyme and its recircularization with T4 DNA ligase after filling of the sticky ends with the Klenow fragment of DNA polymerase I. Loss of the EcoRI site and generation of a new AsnI site in the product plasmid pND721 was confirmed by restriction digestion and gel electrophoresis. A polylinker sequence was then inserted into this plasmid downstream of the T7 promoter and ribosomebinding site by insertion of the 69-bp NdeI-BglII fragment from pMTL22P between the NdeI and BamHI sites of pND721 to yield vector pETMCSI, which is useful for overexpression of genes that have an $\mathrm{NdeI}$ site at their start codon (28). To construct pETMCSII, which is generally useful for overexpression of genes within DNA fragments that already contain a ribosome-binding site and start codon, the 4568-bp XbaI-BamHI fragment of pND721, the 80-bp EcoRV-BglII (polylinker) fragment of pMTL22P, and an equimolar mixture of two complementary (5'-unphosphorylated) oligonucleotides, 5'-CTAGTAATAATTTTGTTA and 5'-TAAACAAAATTATTA, were ligated together. Restriction digestion and nucleotide sequence determination confirmed construction of pETMCSII. Next, the 1483-bp Met-His $6_{6}$ gene $\mathrm{II}^{+}$BamHI-BglII fragment from pCL477 was ligated with pETMCSII that had been linearized with BamHI and 5'-dephosphorylated with alkaline phosphatase. Transformants of AN1459 were screened for plasmids that contained gene II in the orientation appropriate for its expression from the T7 promoter, yielding plasmid pCL773 (6148 bp). This plasmid contains two NdeI sites, one at each end of the gene II insert. Deletion of the 1448-bp NdeI fragment yielded vector pETMCSIII (see Supporting Information).

Plasmids for Overproduction of Tus. The tus gene was excised from pTH311 (9) by digestion with SalI. The isolated 1724-bp fragment was then digested with AccI, which removed 20 nucleotides from the $5^{\prime}$ end of the gene. The 1159-bp AccI-SalI fragment, an equimolar mixture of complementary oligonucleotides 5'-TATGGCGCGTTACGATCTCGT and 5'-CTACGAGATCGTAACGCGCCA, and the 4307-bp NdeI-SalI fragment of vector pND706 (25) were ligated together to yield plasmid pCM847 (Figure 1A). This manipulation effectively restored the $5^{\prime}$ end of the gene, now with an NdeI site at the start codon, and placed tus 


\begin{tabular}{|c|c|c|}
\hline mutation & new site & primers $\left(5^{\prime}\right.$ to $\left.3^{\prime}\right)$ \\
\hline K89A & $B g l I I$ & CTTTTAAGATCTAGCGCGGCCGCCGTACGTCTGCCTGGCGTG ${ }^{b}$ \\
\hline & & 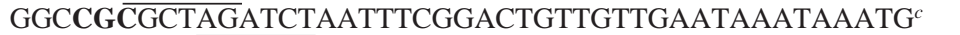 \\
\hline A173T & $A f l I I$ & 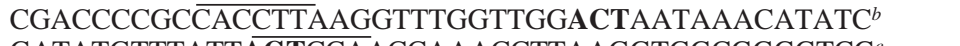 \\
\hline & & GATATGTTTATTĀGTCCAACCAAACCTTAAGGTGGCGGGGTCG ${ }^{c}$ \\
\hline R198A & MunI & $\begin{array}{l}\text { TCCTGGCACAATTGGAAAAAAGCCTGAAATCACCAGCCAGTGTCGC }{ }^{b} \\
\text { primer } 10(2 \overline{6})^{c, d}\end{array}$ \\
\hline Q250A & MluI & $\begin{array}{l}\text { CCAACACGCGTGCCCTACACCACTG }{ }^{b, e} \\
\text { AGGGCACGCGTGTTGGACCGCTTTTTGATCTCCTTT }^{c}\end{array}$ \\
\hline
\end{tabular}

\footnotetext{
${ }^{a}$ Introduced restriction endonuclease sites are underlined, and the new codon (or its complement) is shown in bold. ${ }^{b}$ Primers used with primer 10 (26) for PCR amplification of the 3'-portion of the gene. ${ }^{c}$ Primer used with primer 9 (26) for amplification of the $5^{\prime}$-portion of the gene. ${ }^{d}$ The template was a $t u s$ derivative that already contained a $M u n \mathrm{I}$ site at the required position. ${ }^{e}$ Digested with $M l u \mathrm{I}$ and $P v u \mathrm{II}$ (see text).
}
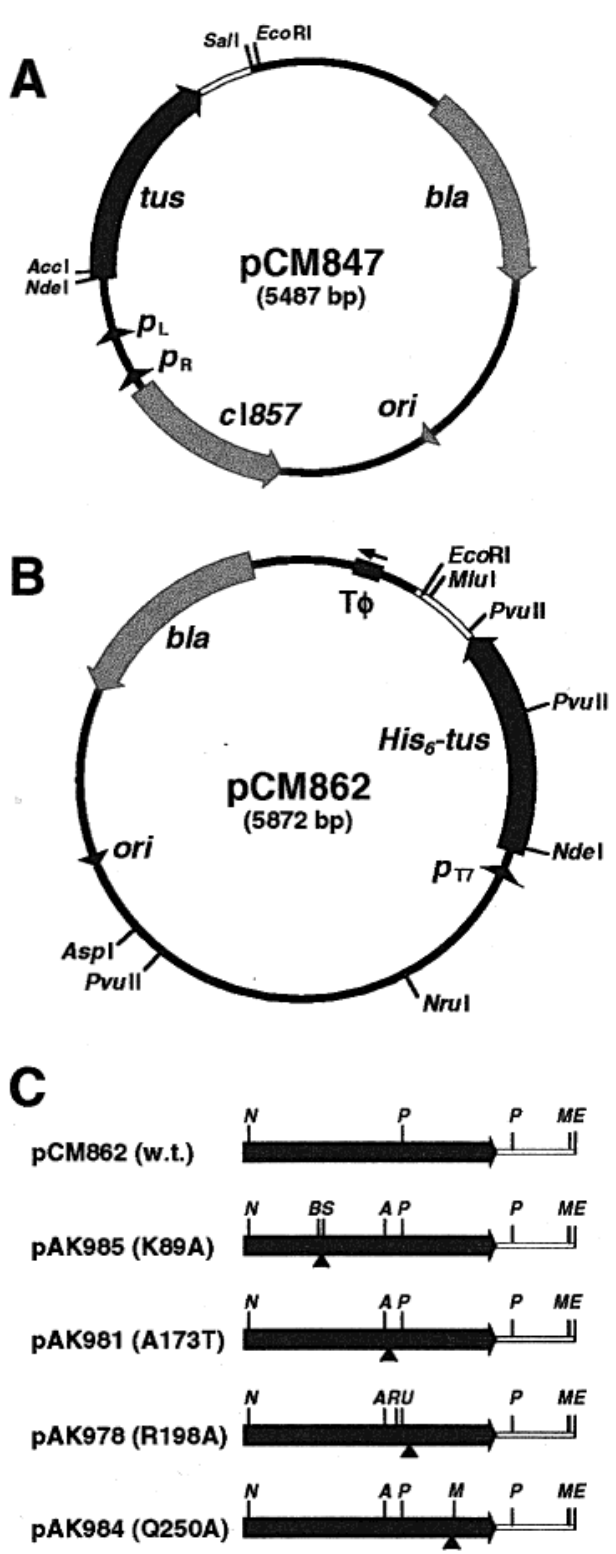

FIGURE 1: Plasmids used for overexpression of Tus (A), His 6 -Tus (B), and His $_{6}$-Tus mutants (C). (A) Plasmid pCM847 is a derivative of the bacteriophage $\lambda$ promoter vector pND706 (25). (B) Plasmid pCM862 is a derivative of the T7 promoter vector pETMCSIII. (C) NdeI-EcoRI fragments inserted in pETMCSIII to generate pCM862 and plasmids containing mutant tus genes. The filled boxes represent tus, and sites of mutations are indicated by arrowheads. Restriction sites: A, AflII; $B, B g l \mathrm{II} ; E, E c o \mathrm{RI} ; M, M l u \mathrm{I} ; N, N d e \mathrm{I}$; $P, P v u \mathrm{II} ; R, N r u \mathrm{I} ; S, B s i \mathrm{WI}$; $U$, MunI.

downstream of the tandem heat-inducible bacteriophage $\lambda$ promoters and ribosome-binding site in the vector. To overproduce Tus with an N-terminal Met-His 6 tag, the 1204bp tus $^{+}$NdeI-EcoRI fragment of pCM847 was inserted between the corresponding sites in pETMCSIII to give plasmid pCM862 (Figure 1B).

Mutagenesis of tus. Genes coding for mutant proteins were constructed by PCR using as template pCM847 or a close derivative of it that contained tus that had already been modified to introduce restriction sites (for facilitation of generation of further mutations in the core DNA-binding regions) without changing the protein sequence (i.e., silent mutations; see Figure 1C). For construction of the mutants described here, the appropriate codon was altered concomitantly with introduction nearby of further silent mutations that led to the formation of a restriction endonuclease site. In general, the $3^{\prime}$-portion of the gene was amplified using a mutagenic primer (Table 1) and primer 10 (above). When necessary, the $5^{\prime}$-portion of the gene was amplified separately using primer 9 (above) and a partially complementary mutagenic primer (Table 1) that introduced the same restriction site. For all but the Q250A mutation, PCR-generated fragments were then digested with restriction endonucleases that cleaved at the introduced site and NdeI or EcoRI, as appropriate, ligated and inserted between the NdeI and EcoRI sites of pETMCSIII for overexpression of $\mathrm{His}_{6}$-tagged proteins in BL21(DE3). A similar strategy was employed for Q250A, except that because of the presence of an extra MluI site in the NdeI-EcoRI (tus) fragment, four fragments were ligated together: the $N d e \mathrm{I}-E c o$ RI fragment of $\mathrm{pET}$ MCSIII (4667 bp), the 230-bp PvuII-EcoRI fragment from pAK978 (below), and the PCR-generated NdeI-MluI (760 bp) and MluI-PvuII (215 bp) fragments (Figure 1C). Nucleotide sequences of all mutant tus genes were determined in their entirety. The plasmids that finally directed overexpression of His $_{6}$-Tus-K89A, His $6_{6}$-Tus-A173T, His $6^{-}$ Tus-R198A, and His $_{6}$-Tus-Q250A were pAK985, pAK981, pAK978, and pAK984, respectively (Figure 1C).

Purification of Wild-Type Tus. Strain AN1459/pCM847 was grown to $A_{595}=0.5-0.6$ at $30{ }^{\circ} \mathrm{C}$ and induced to express Tus by a rapid temperature shift to $42{ }^{\circ} \mathrm{C}$, followed by incubation at this temperature for $2 \mathrm{~h}$. The cells from $4 \mathrm{~L}$ of culture (ca. $8 \mathrm{~g}$, wet weight) were harvested, frozen in liquid $\mathrm{N}_{2}$, and stored at $-80^{\circ} \mathrm{C}$. The frozen cells were thawed at $0{ }^{\circ} \mathrm{C}$ and suspended in ice-cold lysis buffer (50 mM Tris. $\mathrm{HCl}, \mathrm{pH} 7.6,10 \% \mathrm{w} / \mathrm{v}$ sucrose, $0.1 \mathrm{M} \mathrm{NaCl}, 2 \mathrm{mM}$ DTT, $10 \mathrm{mM}$ spermidine $3 \mathrm{HCl} ; 15 \mathrm{~mL} / \mathrm{g}$ of cells). Lysozyme was added to a concentration of $0.2 \mathrm{mg} / \mathrm{mL}$, and the suspension was stirred at $0{ }^{\circ} \mathrm{C}$ for $2 \mathrm{~h}$, followed by treatment at $37^{\circ} \mathrm{C}$ for $4 \mathrm{~min}$ before being stirred again in an ice bath for 30 
min. The cell lysate was cleared by centrifugation, and Tus protein was precipitated from the supernatant by the addition of $\left(\mathrm{NH}_{4}\right)_{2} \mathrm{SO}_{4}(0.36 \mathrm{~g} / \mathrm{mL})$ over $30 \mathrm{~min}$. The pellet obtained after centrifugation was dissolved in $4 \mathrm{~mL}$ of buffer $\mathrm{A}$ (50 $\mathrm{mM}$ imidazole $\cdot \mathrm{HCl}, \mathrm{pH} 7.4,1 \mathrm{mM}$ EDTA, $1 \mathrm{mM}$ DTT) and dialyzed vs buffer A at $4{ }^{\circ} \mathrm{C}$. The dialysate was loaded onto a column $(2.5 \times 20 \mathrm{~cm})$ of DEAE-Fractogel (Merck) and eluted with a gradient of $0-1 \mathrm{M} \mathrm{NaCl}$ over $900 \mathrm{~mL}$ in buffer A. The native Tus protein eluted from the column at about $0.2 \mathrm{M} \mathrm{NaCl}$. Fractions containing Tus were combined and exchanged into buffer B (50 mM phosphate, $\mathrm{pH} 6.8,50 \mathrm{mM}$ $\mathrm{NaCl}, 1 \mathrm{mM}$ DTT, $0.1 \mathrm{mM}$ EDTA) by dialysis. The dialysate was loaded onto a column $(2.5 \times 20 \mathrm{~cm})$ of phosphocellulose (Whatman P11) and eluted with a gradient of $0.05-1.05 \mathrm{M}$ $\mathrm{NaCl}$ in buffer B $(500 \mathrm{~mL})$. Tus eluted at about $0.3 \mathrm{M} \mathrm{NaCl}$. Protein was precipitated from appropriate fractions with $\left(\mathrm{NH}_{4}\right)_{2} \mathrm{SO}_{4}(0.36 \mathrm{~g} / \mathrm{mL})$. Following centrifugation, the pellet was dissolved in the minimum volume of buffer $\mathrm{B}$. This solution was loaded onto a column $(2.5 \times 80 \mathrm{~cm})$ of Sephadex G-50 (Pharmacia) equilibrated in buffer B. Pure Tus eluted in the void volume. The yield of protein was about $15 \mathrm{mg} / \mathrm{L}$ of culture.

Purification of His $\sigma_{6}$-Tagged Tus Proteins. BL21(DE3) strains containing plasmids directing the overproduction of His $_{6}$-tagged Tus proteins were grown at $37{ }^{\circ} \mathrm{C}$ to $A_{595} \sim 0.5$. The expression of Tus proteins was induced by the addition of IPTG to $1 \mathrm{mM}$. Cells were harvested after $2-3 \mathrm{~h}$. They were lysed, and the proteins were partially purified by $\left(\mathrm{NH}_{4}\right)_{2}-$ $\mathrm{SO}_{4}$ precipitation and chromatography on DEAE-Fractogel as described above. Fractions containing Tus were combined and loaded directly onto the phosphocellulose column and eluted with a salt gradient as described for the wild-type protein. The His ${ }_{6}$-tagged proteins, being more basic, eluted at high salt concentrations (between 0.9 and $1.05 \mathrm{M} \mathrm{NaCl}$ ) and required no further purification. The yield of $\mathrm{His}_{6}$-Tus and the mutants His $_{6}$-Tus-K89A, His 6 -Tus-A173T, His 6 -TusR198A, and His $_{6}$-Tus-Q250A varied between 3 and $4 \mathrm{mg} / \mathrm{L}$ of culture. While the His 6 -tagged proteins could also be purified by chromatography on chelated $\mathrm{Ni}$ (II) resins, with subsequent extensive dialysis against buffers containing EDTA, the proteins gave poor ESI mass spectra and behaved inconsistently in the BIACORE studies. The reason for this behavior has not been established.

Characterization of Tus Proteins. The final fractions containing Tus protein were exchanged into storage buffer (50 mM Tris $\cdot \mathrm{HCl}, \mathrm{pH} 7.5,100 \mathrm{mM} \mathrm{NaCl}, 1 \mathrm{mM}$ DTT, 1 mM EDTA, 20\% w/v glycerol), concentrated using a vacuum dialysis apparatus (Schleicher and Schuell), and stored at -80 ${ }^{\circ} \mathrm{C}$. Tus concentrations were determined from its UV absorption spectrum using $\epsilon_{280}=39700 \mathrm{M}^{-1} \mathrm{~cm}^{-1}$ (29). Protein samples for ESI-MS were prepared by diluting the protein stock to $0.5 \mathrm{mg} / \mathrm{mL}$ in water, followed by extensive dialysis against $0.1 \%$ formic acid. Mass spectra were collected on a VG Biotech Quattro II mass spectrometer.

Surface Plasmon Resonance Measurements. The TusTerB interaction was studied using a BIACORE 2000 instrument, operated at $25^{\circ} \mathrm{C}$. Protein solutions were diluted in binding buffer $(50 \mathrm{mM}$ Tris $\cdot \mathrm{HCl}, 0.1 \mathrm{mM}$ EDTA, $0.1 \mathrm{mM}$ DTT, $0.005 \%$ Nonidet P-20) containing varying concentrations of $\mathrm{KCl}(100-400 \mathrm{mM})$, with the $\mathrm{pH}$ adjusted to 7.5. The general experimental design was to immobilize biotinlabeled oligodeoxynucleotides at low levels (10-40 RU) in

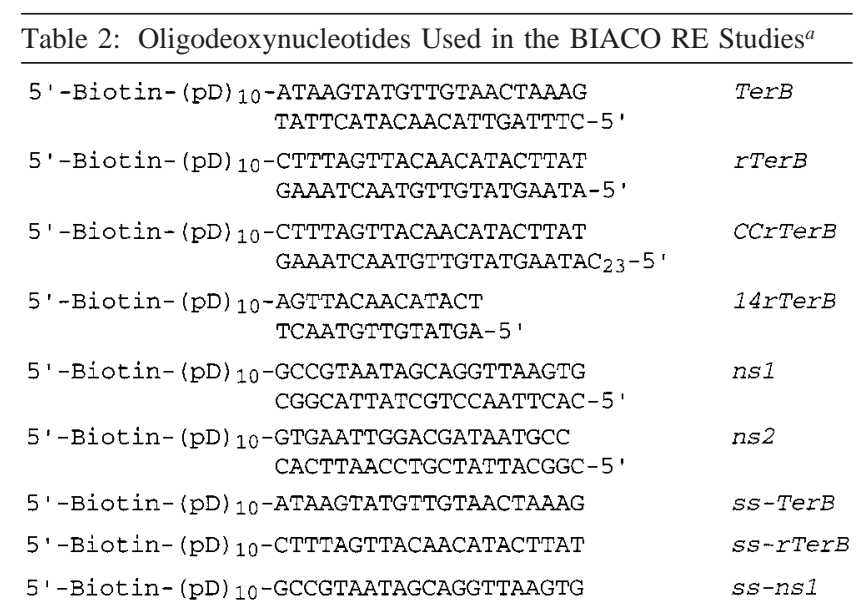

$a$ The sequence of the DNA is shown as well as the attachment of the biotin moiety. Each DNA molecule has a 10-unit abasic deoxyribose phosphate spacer $(\mathrm{pD})_{10}$ to move it away from the surface of the BIACORE chip.

the flow cells of a streptavidin-coated BIACORE chip, with flow cell no. 1 left unmodified as a control. Tus binding was monitored using a flow rate of $40 \mu \mathrm{L} / \mathrm{min}$. The association phase with Tus solutions was monitored for $2-5$ min; then binding buffer was applied, and the dissociation phase was followed for $10 \mathrm{~min}$. The surface was regenerated using binding buffer containing $1 \mathrm{M} \mathrm{KCl}$ (over $5 \mathrm{~min}$ ), which led to complete dissociation of the Tus-TerB complexes. The oligonucleotides used in this study are shown in Table 2. All biotin moieties were attached at a $5^{\prime}$ end, and the (abasic) deoxyribose $5^{\prime}$-phosphate $(\mathrm{pD})$ units were used as spacers to ensure that access of Tus to the DNA was not hindered by the streptavidin surface. Most work was done with a ds-oligonucleotide (labeled TerB in Table 2), a 21bp sequence containing the TerB site. Tus would bind to this ligand with its permissive face away from the surface of the BIACORE chip. Five other ds-oligodeoxynucleotides were used to examine the effect of DNA structure and orientation on binding. A reverse TerB $(r \operatorname{Ter} B)$ was identical to $\operatorname{Ter} B$ except that when immobilized it exposes the replication blocking (nonpermissive) face. $C \mathrm{CrTer} B$ was a reverse TerB which is identical to $r \operatorname{Ter} B$ except that the DNA has a 5' ss-tail of 23 cytosine nucleotides oriented away from the surface, and $14 r T e r B$ closely resembled the oligonucleotide used in the Tus-DNA crystal structure determination (18). It is a shorter, 14-bp oligonucleotide in the same orientation as $r$ TerB but missing the first four and last three nucleotides. Two other "random" ds-oligonucleotides, which had no resemblance to the TerB site, were used to assess nonspecific DNA binding by Tus ( $n s 1$ and $n s 2)$. The interaction of Tus with ss-DNA was examined using the $5^{\prime}$ biotinylated strands of TerB (ss-TerB), rTerB (ss-rTerB), and $n s 1$ (ss-ns1). Equilibrium (dissociation constant, $K_{\mathrm{D}}$ ) and kinetic (rate constants, $k_{\mathrm{a}}$ and $k_{\mathrm{d}}$ ) parameters for the binding of Tus proteins to the ds-TerB fragments were generally determined in binding buffer containing $250 \mathrm{mM} \mathrm{KCl}$. The binding of Tus proteins to the two nonspecific ds-DNA molecules (ns1 and $n s 2)$ and some ss-DNA fragments was examined in binding buffer containing $100 \mathrm{mM} \mathrm{KCl}$. In most experiments, the binding of the Tus proteins to the oligonucleotides was measured simultaneously on two surfaces which had different levels of DNA immobilized. To test the 
effect of free $\operatorname{Ter} B$ on the rate of dissociation of $\mathrm{His}_{6}$-Tus from TerB in binding buffer containing $250 \mathrm{mM} \mathrm{KCl}$, the BIACORE function COINJECT was used to inject $50 \mathrm{nM}$ His $_{6}$-Tus for $4 \mathrm{~min}$ (association phase), immediately followed by $1 \mu \mathrm{M} \operatorname{Ter} B$ [without $5^{\prime}$-biotin or $(\mathrm{pD})_{10}$ spacer] for $5 \mathrm{~min}$ (dissociation phase).

Data Analysis. The data were fitted using the BIAevaluation software version 3.0.2 (BIACORE AB). Where possible, $K_{\mathrm{D}}$ was calculated using both kinetic and equilibrium data. In all cases, the control surface response was a simple refractive index change, and after $x$-alignment of the curves, this was subtracted from all binding data before fitting. The equilibrium $K_{\mathrm{D}}$ was calculated by fitting the curve of equilibrium response vs [Tus protein] to a 1:1 binding model. In most cases, rate constants were calculated by global fitting of the association and dissociation phases of the response curves. Either a simple 1:1 binding model or a 1:1 binding with mass transfer model was used. The latter model was only used if it gave a significantly better fit than the simpler 1:1 model. Fits were considered satisfactory if $\chi^{2} \leq 3$. For experimentally determined parameters, the quoted errors are either the standard error reported by BIAevaluation (for parameters which were determined from one data set) or the appropriately propagated errors from multiple data sets. More details of the error calculations can be found in the footnotes in the Tables.

\section{RESULTS}

Overproduction, Purification, and Characterization of Tus Proteins. An enriched source of wild-type Tus was generated following insertion of the gene into the $\lambda$ promoter vector pND706 to yield plasmid pCM847 (Figure 1A), which directed thermally induced overproduction of the protein to very high levels (not shown). For production of N-terminal His $_{6}$-tagged Tus, we first constructed pETMCSIII, a new derivative of the bacteriophage $\mathrm{T} 7$ promoter vector $\mathrm{pET} 3 \mathrm{c}$ (27) and then inserted tus from pCM847 into it to give pCM862 (Figure 1B). PCR was then used to modify the tus gene to create four separate mutants (Figure 1C) that express variant Tus proteins with changes at residues that make sitespecific contacts to the $\operatorname{Ter} B$ binding site, as revealed in the crystal structure of the Tus-TerB complex (18). It was the purpose of this work to use these variant Tus proteins to gain insights into the mechanism of Tus-Ter interaction.

A straightforward method was devised for purification of Tus, $\mathrm{His}_{6}$-Tus, and the $\mathrm{His}_{6}$-Tus variants, involving gentle lysis of cells from strains expressing the proteins, fractionation with ammonium sulfate, and chromatography on DEAE-Fractogel and phosphocellulose. In comparison with the His $_{6}$-tagged proteins, unmodified Tus eluted at lower $[\mathrm{NaCl}]$ from phosphocellulose, which necessitated a further gel filtration step. All of the Tus proteins, obtained in yields of up to $15 \mathrm{mg} / \mathrm{L}$ of culture, were judged to be pure by SDSPAGE analysis (Figure 2). The molecular masses and amino acid compositions of the proteins were confirmed by ESI-MS: for wild-type Tus, calculated 35652 , found $35653 \pm 1 \mathrm{Da}$; for $\mathrm{His}_{6}$-Tus, calculated 36737 , found $36741 \pm 3$ Da; for His $_{6}$-K89A-Tus, calculated 36 680, found 36681 土 $1 \mathrm{Da}$; for His 6 -Tus-A173T, calculated 36767 , found $36768 \pm 2 \mathrm{Da}$; for His $_{6}$-Tus-R198A, calculated 36 652, found $36652 \pm 3 \mathrm{Da}$; for His6-Tus-Q250A, calculated 36 680, found $36680 \pm 2 \mathrm{Da}$.

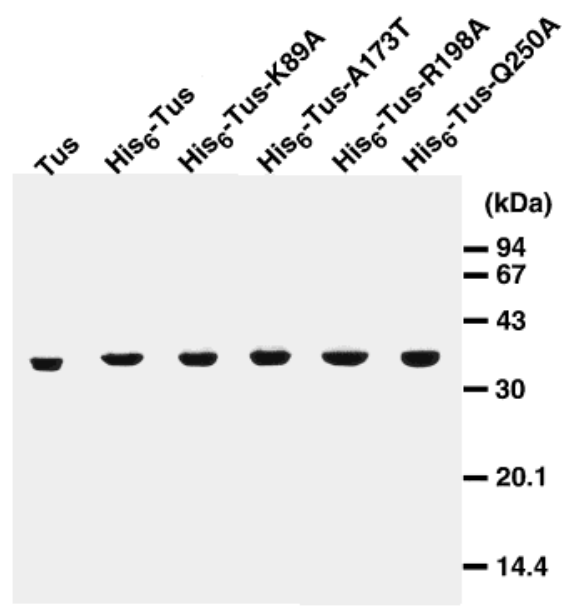

FIGURE 2: SDS-PAGE of purified Tus proteins. The 15\% polyacrylamide gel was stained with Coomassie blue. The same amount $(6.0 \mu \mathrm{g})$ of each of the proteins was applied to the gel, after it had been denatured in a loading buffer ( $\mathrm{pH}$ 6.8) containing SDS. The positions of bands of molecular mass marker proteins were as indicated (in kilodaltons).

Table 3: Kinetic and Steady-State Parameters for the 1:1 Interaction of Tus and Its Variants with $\operatorname{Ter} B$ in $250 \mathrm{mM} \mathrm{KCl}^{a}$

\begin{tabular}{lcccc}
\hline Tus protein & $\begin{array}{c}10^{3} k_{\mathrm{d}}^{b, c} \\
\left(\mathrm{~s}^{-1}\right)\end{array}$ & $\begin{array}{c}10^{-6} k_{\mathrm{a}}^{b, c} \\
\left(\mathrm{M}^{-1} \mathrm{~s}^{-1}\right)\end{array}$ & $\begin{array}{c}k_{\mathrm{d}} / k_{\mathrm{a}}=K_{\mathrm{D}}{ }^{c} \\
(\mathrm{nM})\end{array}$ & $\begin{array}{c}K_{\mathrm{D}}{ }^{c, d} \\
(\mathrm{nM})\end{array}$ \\
\hline wild type & $7(1)$ & $7(2)$ & $1.0(0.3)$ & - \\
His $_{6}$ & $5(2)$ & $12(4)$ & $0.5(0.2)$ & - \\
His $_{6}$-K89A & $134(4)$ & $1.2(0.2)$ & $110(20)$ & $90(5)$ \\
His $_{6}$-A173T & $700(100)$ & $0.35(0.06)$ & $-e$ & $2000(200)^{e}$ \\
His $_{6}$-R198A & $19(2)$ & $0.142(0.004)$ & $130(10)$ & $192(3)$ \\
His $_{6}$-Q250A & $280(40)$ & $1.3(0.5)$ & $220(80)$ & $100(10)$ \\
\hline
\end{tabular}

${ }^{a}$ In binding buffer $(50 \mathrm{mM}$ Tris $\cdot \mathrm{HCl}, \mathrm{pH} 7.5,0.1 \mathrm{mM}$ EDTA, 0.1 mM DTT, $0.005 \%$ Nonidet P-20) at $25{ }^{\circ} \mathrm{C} .{ }^{b}$ The kinetic data for wild type and $\mathrm{His}_{6}$-Tus were fitted using a 1:1 binding with mass transfer model. The kinetic data for the Tus variants were fitted using a 1:1 binding model. ${ }^{c}$ The kinetic and steady-state data collected from at least two different immobilization levels of TerB were fitted independently, and the mean was calculated. The errors determined for these independent data sets (the standard error from the BIAevaluation software) were insignificant relative to the differences between the data sets, so the calculated error (shown in parentheses) is the standard deviation of the mean. The error on $k_{\mathrm{d}} / k_{\mathrm{a}}$ has been propagated from the associated errors on $k_{\mathrm{d}}$ and $k_{\mathrm{a}}{ }^{d}$ The steady-state $K_{\mathrm{D}}$ of wild type and His $6_{-}$-Tus complexes with TerB was too low to be determined (see Results section). The steady-state data for the Tus variants were fitted using a 1:1 binding model. ${ }^{e}$ The steady-state $K_{\mathrm{D}}$ for His 6 -Tus-A173T was determined from only one data set, so the error is the standard error reported by the BIAevaluation software. The association rate for this protein was too fast to be measured, so $k_{\mathrm{a}}$ was calculated from the measured $k_{\mathrm{d}}$ and the steady-state value of $K_{\mathrm{D}}$, and the errors were propagated appropriately.

Binding of Tus and Tus Variants to TerB. The Tus-TerB interaction was studied using a BIACORE 2000 instrument, using various $5^{\prime}$-biotinylated $\operatorname{TerB}$ oligonucleotides (Table 2 ) immobilized on a streptavidin-coated surface. At low ionic strength, in accord with expectations based on the literature (19), Tus bound quantitatively to $\operatorname{TerB}$ with association rates that were immeasurably fast and dissociation rates that were immeasurably slow. Therefore, to provide meaningful comparisons among the various proteins, most of the measurements reported here were made at $25^{\circ} \mathrm{C}$ in $50 \mathrm{mM}$ Tris, $\mathrm{pH}$ 7.5 , containing $250 \mathrm{mM} \mathrm{KCl}$.

The results for the binding of Tus and its variants to TerB under these conditions are summarized in Table 3. Typical 

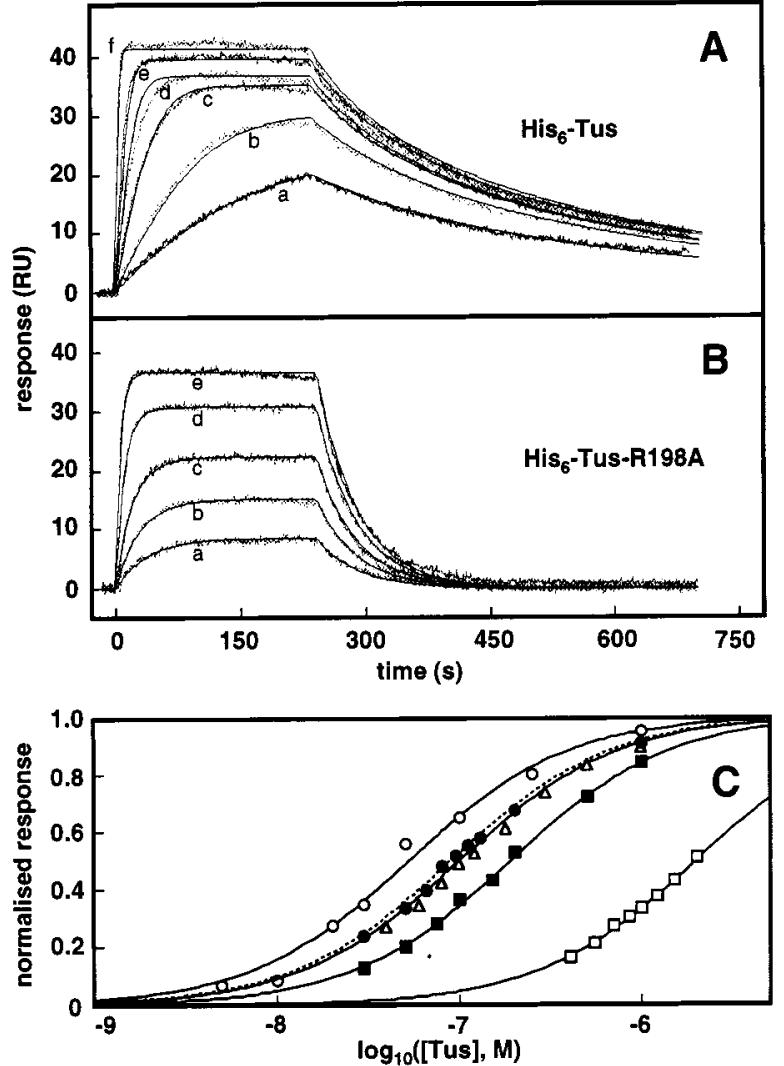

FIGURE 3: Selected BIACORE data for the interaction of $\mathrm{His}_{6}$ Tus and mutants with TerB and $14 r T e r B$ in $250 \mathrm{mM} \mathrm{KCl}$. Experimental and fitted kinetic data for the interaction of $\mathrm{His}_{6}$-Tus (A) and His $_{6}$-Tus-R198A (B) with TerB. The data were fitted to a 1:1 binding model, including a mass transfer parameter in the case of His $_{6}$-Tus, as shown by the solid lines. For His ${ }_{6}$-Tus, the curves shown are at protein concentrations of (a) $1 \mathrm{nM}$, (b) $2 \mathrm{nM}$, (c) 5 $\mathrm{nM}$, (d) $10 \mathrm{nM}$, (e) $15 \mathrm{nM}$, and (f) $50 \mathrm{nM}$. Data collected and fitted at $\left[\right.$ His $_{6}$-Tus $]=20$ and $30 \mathrm{nM}$ have been omitted for clarity. For His $_{6}$-Tus-R198A, the curves shown are at protein concentrations of (a) $50 \mathrm{nM}$, (b) $100 \mathrm{nM}$, (c) $200 \mathrm{nM}$, (d) $500 \mathrm{nM}$, and (e) 1000 nM. Data collected and fitted at [His 6 -Tus-R198A] $=30,75$, and $150 \mathrm{nM}$ have been omitted for clarity. (C) Steady-state data for the interaction of $\mathrm{His}_{6}$-Tus with $14 r \mathrm{TerB}(\mathrm{O})$ and of $\mathrm{His}_{6}$-Tus-K89A $(\bullet)$, His $_{6}$-Tus-A173T ( $\square$ ), His 6 -Tus-R198A (ם), and His 6 -TusQ250A $(\triangle)$ with $\operatorname{Ter} B$. The fitted data for a 1:1 binding model are shown as solid lines. The responses have been normalized using the fitted value for the maximum response at equilibrium.

data used for determination of both the kinetic and thermodynamic parameters are shown in Figure 3 . Values of the dissociation rate constant $\left(k_{\mathrm{d}}\right)$ could be determined directly for all Tus proteins, and values of the association rate constant $\left(k_{\mathrm{a}}\right)$ could be determined for all except His $_{6}$-TusA173T, for which the association occurred too rapidly. The kinetically determined $K_{\mathrm{D}}\left(=k_{\mathrm{d}} / k_{\mathrm{a}}\right)$ could thus be calculated for all proteins except $\mathrm{His}_{6}$-Tus-A173T. The $K_{\mathrm{D}}$ values were also determined from the equilibrium response for all proteins except wild-type and $\mathrm{His}_{6}$-Tus (see Figure 3C), for which the response of the instrument at the necessary protein concentrations $(<1 \mathrm{nM})$ was too small to be measured accurately. The values of $K_{\mathrm{D}}$ calculated from the equilibrium and the kinetic data otherwise agreed to within a factor of 2. This provides a measure of the precision of the various measurements and reliability of the fit to a 1:1 binding model and suggests that observed differences greater than 2-fold are significant. The stoichiometry of binding at saturation was observed to be between 1.0 and $1.2 \mathrm{~mol} / \mathrm{mol}$ (protein:
Table 4: Effect of $\mathrm{KCl}$ Concentration on Kinetic and Steady-State Parameters for the 1:1 Interaction of $\mathrm{His}_{6}$-Tus with $\operatorname{TerB}^{a}$

\begin{tabular}{ccccc}
\hline $\begin{array}{c}\mathrm{KCl}] \\
(\mathrm{mM})\end{array}$ & $\begin{array}{c}10^{3} k_{\mathrm{d}}{ }^{b} \\
\left(\mathrm{~s}^{-1}\right)\end{array}$ & $\begin{array}{c}10^{-6} k_{\mathrm{a}}{ }^{b} \\
\left(\mathrm{M}^{-1} \mathrm{~s}^{-1}\right)\end{array}$ & $\begin{array}{c}k_{\mathrm{d}} / k_{\mathrm{a}}=K_{\mathrm{D}}{ }^{b} \\
(\mathrm{nM})\end{array}$ & $\begin{array}{c}K_{\mathrm{D}}{ }^{c} \\
(\mathrm{nM})\end{array}$ \\
\hline 250 & $4.35(0.03)$ & $17.5(0.2)$ & $0.25(0.003)$ & $0.53(0.1)$ \\
300 & $5.30(0.01)$ & $2.16(0.01)$ & $2.45(0.01)$ & $3.1(0.1)$ \\
350 & $5.66(0.01)$ & $0.422(0.002)$ & $13.4(0.1)$ & $15^{d}(1)$ \\
400 & $7.15(0.01)$ & $0.0922(0.0003)$ & $77.5(0.6)$ & $71(5)$ \\
\hline
\end{tabular}

${ }^{a}$ In binding buffer $(50 \mathrm{mM}$ Tris $\cdot \mathrm{HCl}, \mathrm{pH}$ 7.5, $0.1 \mathrm{mM}$ EDTA, 0.1 mM DTT, $0.005 \%$ Nonidet P-20) at $25{ }^{\circ} \mathrm{C} .{ }^{b}$ The kinetic data at 250 and $300 \mathrm{mM} \mathrm{KCl}$ were fitted using a 1:1 binding with mass transfer model, and the kinetic data at 350 and $400 \mathrm{mM} \mathrm{KCl}$ were fitted using a 1:1 binding model. The kinetic data from two different immobilization levels of TerB were fitted simultaneously, so the errors (shown in parentheses) are the standard errors reported by the BIAevaluation software. The error in $k_{\mathrm{d}} / k_{\mathrm{a}}$ has been propagated from the associated errors in $k_{\mathrm{a}}$ and $k_{\mathrm{d}} .{ }^{c}$ All steady-state data were fitted using a 1:1 binding model. The data collected from at least two different immobilization levels of $\operatorname{Ter} B$ were fitted independently. As the standard errors of these independent data sets (reported by the BIAevaluation software) were significant relative to the differences between the data sets, the weighted mean and standard deviation were calculated using the standard error as the weights. ${ }^{d}$ The steady-state $K_{\mathrm{D}}$ at $350 \mathrm{mM} \mathrm{KCl}$ was determined from only one data set, so the error is the standard error reported by the BIAevaluation software.

DNA) in all experiments. Within experimental error, the rate of dissociation of the His 6 -Tus-TerB complex was not affected by the presence of excess free $\operatorname{Ter} B$ [without $5^{\prime}$ biotin or $(\mathrm{pD})_{10}$ spacer].

The binding parameters for wild-type and $\mathrm{His}_{6}$-Tus were not distinguishable, with $K_{\mathrm{D}} \sim 0.5 \mathrm{nM}$. However, each of the mutations was found to lead to a decrease in $k_{\mathrm{a}}$ and an increase in $k_{\mathrm{d}}$, relative to values for $\mathrm{His}_{6}$-Tus. The A173T and R198A substitutions gave rise to a 35-80-fold decrease in $k_{\mathrm{a}}$, whereas the K89A and Q250A substitutions led to smaller decreases (10-fold). Conversely, the R198A subsitution caused a modest 4-fold increase in $k_{\mathrm{d}}$, whereas the other substitutions produced a much larger increase (10-140-fold). The $K_{\mathrm{D}}$ values were thus increased 200-300-fold by the K89A, R198A, and Q250A substitutions and 4000-fold by the A173T substitution (Table 3).

Within the limits of experimental error, the binding of $\mathrm{His}_{6}$-Tus and the four variants to $r$ TerB and $C C r T e r B$ was indistinguishable from their binding to $\operatorname{Ter} B$ (data not shown). However, $K_{\mathrm{D}}$ for the $\mathrm{His}_{6}$-Tus complex with $14 r \mathrm{rTerB}$ was significantly higher than with $\operatorname{Ter} B$ (see Figure 3C): the kinetically determined $K_{\mathrm{D}}$ of the His $_{6}$-Tus $-14 r T e r B$ complex was $55 \pm 1 \mathrm{nM}$, as determined from $k_{\mathrm{a}}=(2.07 \pm 0.03) \times$ $10^{6} \mathrm{M}^{-1} \mathrm{~s}^{-1}$ and $k_{\mathrm{d}}=0.113 \pm 0.001 \mathrm{~s}^{-1}$. This value was in good agreement with the value of $53 \pm 6 \mathrm{nM}$ determined from the equilibrium data. The binding of $\mathrm{His}_{6}$-Tus to $14 r T e r B$ is thus 100 -fold weaker than the binding to the 21 mer $\operatorname{Ter} B$ site, due to a 6-fold decrease in the association rate and a 23 -fold increase in the dissociation rate. This indicates that nucleotides in the complete TerB site beyond those in $14 r T e r B$ are required for proper binding. No significant binding of the mutant Tus proteins to $14 \mathrm{rTerB}$ could be detected under these conditions.

Effect of [KCl] on the Tus-TerB Interaction. The salt dependence of binding of $\mathrm{His}_{6}$-Tus to TerB was examined by determination of $K_{\mathrm{D}}, k_{\mathrm{a}}$, and $k_{\mathrm{d}}$ from data obtained using 250-400 mM KCl (Table 4, Figure 4). This increase in $[\mathrm{KCl}]$ led to a large increase in $K_{\mathrm{D}}$. This is primarily the 

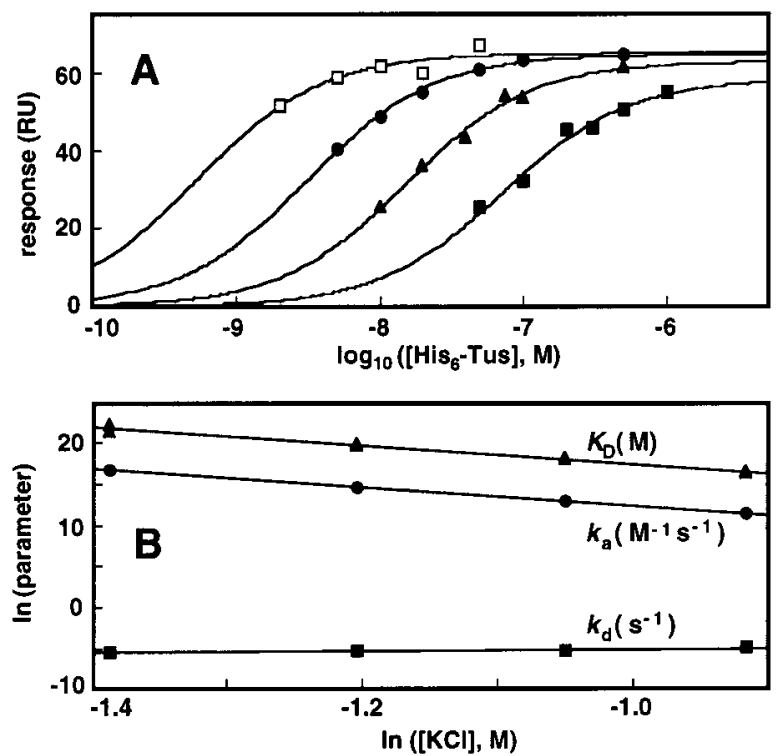

FIGURE 4: Equilibrium and kinetic data for the interaction of $\mathrm{His}_{6}{ }^{-}$ Tus with $\operatorname{Ter} B$ at varying concentrations of $\mathrm{KCl}$. (A) Experimental points obtained at $[\mathrm{KCl}]=250 \mathrm{mM}(\square), 300 \mathrm{mM}(\bullet), 350 \mathrm{mM}$ $(\boldsymbol{\Delta})$, and $400 \mathrm{mM}(\boldsymbol{\square})$. The data were fitted to a 1:1 binding model, including a mass transfer parameter for the data at 250 and 300 $\mathrm{mM} \mathrm{KCl}$, as is shown by the solid lines. The kinetic data (not shown) gave similar results (see Table 4). (B) Dependence of $K_{\mathrm{D}}(\mathbf{\Delta}), k_{\mathrm{a}}(\mathbf{\bullet})$, and $k_{\mathrm{d}}(\boldsymbol{\square})$ on $[\mathrm{KCl}]$. The plot of $\ln K_{\mathrm{A}}$ against $\ln$ $[\mathrm{KCl}]$ had slope $S K_{\mathrm{A}}=-11.2 \pm 0.5$ and $y$-intercept $=6.2 \pm 0.6$. The plots of $\ln k_{\mathrm{a}}$ and $\ln k_{\mathrm{d}}$ gave slope $S k_{\mathrm{a}}=-11.1 \pm 0.1$ and $y$-intercept $=1.3 \pm 0.1\left(\right.$ for $k_{\mathrm{a}}$ ) and slope $S k_{\mathrm{d}}=1.0 \pm 0.2$ and $y$-intercept $=-4.1 \pm 0.2\left(\right.$ for $\left.k_{\mathrm{d}}\right)$.

result of slower association rates (200-fold), with the dissociation rates showing only a modest increase (2-fold). For data obtained with the His $_{6}$-Tus protein, a plot of $\ln K_{\mathrm{A}}$ (where $K_{\mathrm{A}}=K_{\mathrm{D}}^{-1}$ ) against $\ln [\mathrm{KCl}]$ was linear with slope $S K_{\mathrm{A}}=-11.2 \pm 0.5$ (Figure 4B). Similar plots of the rate constants (Figure 4B) gave slopes $S k_{\mathrm{a}}=-11.1 \pm 0.1$ and $S k_{\mathrm{d}}=1.0 \pm 0.2$. According to the models of Record et al. (30), where the number of cations displaced on binding of a protein to ds-DNA is predicted as $S K_{\mathrm{A}} / 0.88$, these data suggest that 13 cations are displaced on binding of His $_{6}$ Tus to TerB. This may be correlated with the number of ionic contacts made between the protein and the DNA. An analysis of the crystal structure of the Tus-TerB complex $(18,31)$ suggests that there are eight direct ionic contacts between lysine or arginine residues and DNA phosphate groups and probably another two that are water mediated. There are also four probable ionic contacts between protonated histidine residues and DNA phosphates, giving a total of 14 probable ionic contacts.

Nonspecific DNA Binding by Tus. The equilibrium $K_{\mathrm{D}}$ and values of $k_{\mathrm{d}}$ for complexes of the Tus proteins with $n s 1, n s 2$, ss-TerB, ss-rTerB, and ss-ns 1 (Table 2) in buffer containing $100 \mathrm{mM} \mathrm{KCl}$ are listed in Table 5, and some representative data are shown in Figure 5. For all proteins the values of $k_{\mathrm{a}}$ were too high to be determined directly. It is clear that $\mathrm{His}_{6^{-}}$ Tus binds with similarly low affinity to two different dsDNA sequences that are unrelated to $\operatorname{Ter} B$ and also to ssDNA fragments regardless of whether their sequences are related to TerB or not. Furthermore, the K89A, A173T, and Q250A substitutions have no significant effect on His $_{6}$-Tus binding to $n s 1$ and $n s 2$. However, the R198A substitution does decrease the strength of the nonspecific interaction. The
Table 5: Kinetic and Steady-State Parameters for the 1:1 Interaction of Tus and Its Variants with Single-Stranded and Nonspecific Double-Stranded DNA in $100 \mathrm{mM} \mathrm{KCl}^{a}$

\begin{tabular}{llll}
\hline Tus protein & DNA $^{b}$ & $K_{\mathrm{D}}(\mathrm{nM})^{c}$ & $10^{3} k_{\mathrm{d}}\left(\mathrm{s}^{-1}\right)^{c}$ \\
\hline His $_{6}$ & $s s-$ TerB & $180(20)$ & $251(5)$ \\
& $s s-r T e r B$ & $190(20)$ & $219(3)$ \\
& $s s-n s 1$ & $300(40)$ & $226(2)$ \\
& $n s 1$ & $360(30)$ & $298(2)$ \\
His $_{6}-\mathrm{K} 89 \mathrm{~A}$ & $n s 2$ & $480(50)$ & $434(4)$ \\
& $n s 1$ & $530(80)$ & $576(8)$ \\
His $_{6}-\mathrm{A} 173 \mathrm{~T}$ & $n s 2$ & $700(200)$ & $840(20)$ \\
& $n s 1$ & $220(10)$ & $272(2)$ \\
His $_{6}-\mathrm{R} 198 \mathrm{~A}$ & $n s 2$ & $210(10)$ & $356(3)$ \\
& $n s 1$ & $2700(200)^{d}$ & $-e$ \\
His $_{6}-\mathrm{Q} 250 \mathrm{~A}$ & $n s 2$ & $2600(200)^{d}$ & $-e$ \\
& $n s 1$ & $430(20)$ & $297(3)$ \\
& $n s 2$ & $460(10)$ & $434(4)$ \\
\hline
\end{tabular}

${ }^{a}$ In binding buffer $(50 \mathrm{mM}$ Tris $\cdot \mathrm{HCl}, \mathrm{pH} 7.5,0.1 \mathrm{mM}$ EDTA, 0.1 mM DTT, $0.005 \%$ Nonidet P-20) at $25^{\circ} \mathrm{C} .{ }^{b}$ See Table 2. ${ }^{c}$ The kinetic and steady-state data were fitted using a 1:1 binding model. Data were only collected for one immobilization level of DNA, so the errors are the standard errors from the BIAevaluation software, which is why they may appear artificially low. ${ }^{d}$ Fitting of the steady-state data (Figure $5)$ with two parameters gave unrealistic estimates of the response at high [protein], so data were fitted to a single parameter $\left(K_{\mathrm{D}}\right)$ with the maximum response fixed at $170 \mathrm{RU} .{ }^{e}$ The $k_{\mathrm{d}}$ values for $\mathrm{His}_{6}$-TusR198A were too high to be determined accurately.

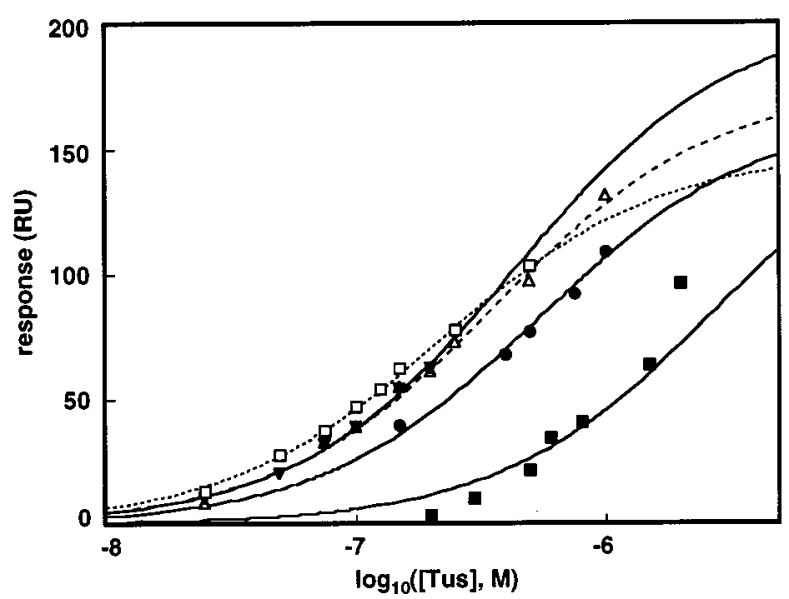

FIGURE 5: Equilibrium data for the interaction of $\mathrm{His}_{6}$-Tus $(\triangle)$, His $_{6}$-Tus-K89A (@), His 6 -Tus-A173T ( $\left.\square\right)$, His 6 -Tus-R198A (ם), and His $_{6}$-Tus-Q250A $(\boldsymbol{\nabla})$ with $n s 1$, in $100 \mathrm{mM} \mathrm{KCl}$. The fitted data for a 1:1 binding model are shown as a solid line. The data collected for $n s 2$ were very similar (not shown).

5-8-fold increase in $K_{\mathrm{D}}$ due to nonspecific interactions thus accounts for a substantial portion of the effect of the R198A mutation on binding to $\operatorname{TerB}$ (in $250 \mathrm{mM} \mathrm{KCl}$; Table 3). Although the difference in salt concentration required for the specific and nonspecific binding measurements makes direct comparisons difficult, it is possible to extrapolate the salt dependence data to $100 \mathrm{mM} \mathrm{KCl}$. This extrapolation suggests that the $K_{\mathrm{D}}$ for the $\mathrm{His}_{6}$-Tus complex with $\operatorname{Ter} B$ at $100 \mathrm{mM} \mathrm{KCl}$ is lower than $1 \times 10^{-12} \mathrm{M}$, with a $k_{\mathrm{a}}$ that is diffusion limited $\left(>10^{9} \mathrm{M}^{-1} \mathrm{~s}^{-1}\right)$ and a $k_{\mathrm{d}}$ of the order of $10^{-3}$ $\mathrm{s}^{-1}$. As the $K_{\mathrm{D}}$ for $\mathrm{His}_{6}$-Tus binding to nonspecific DNA sequences in $100 \mathrm{mM} \mathrm{KCl}$ is about $300 \mathrm{nM}$ (Table 5), the $K_{\mathrm{D}}$ for the specific binding is at least $10^{5}$ times lower. This is in broad agreement with the results of Guajardo and Sousa (32), who used nitrocellulose filter binding assays to determine that the $K_{\mathrm{D}}$ for the binding of Tus to DNA lacking a Ter site is $10^{4}$ times higher than binding to a Ter site (in 


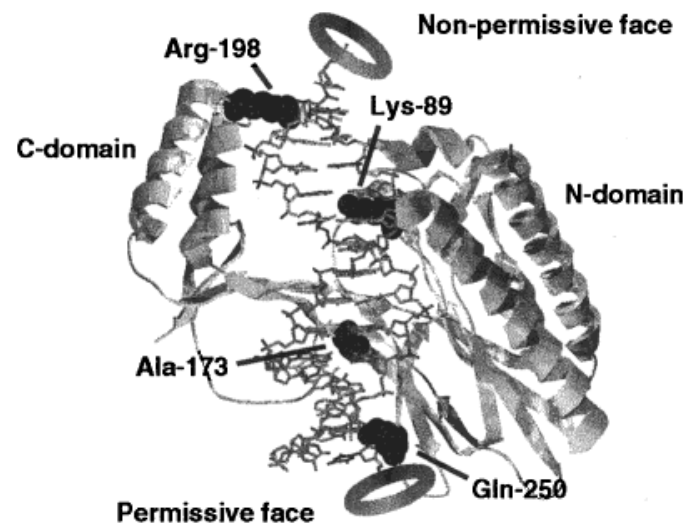

Figure 6: Structure of the Tus-Ter complex (18). The position of the four mutated residues and the orientation of the permissive and nonpermissive faces of the complex are shown. The four $\beta$-strands of the central DNA-binding domain wind around the back of the DNA helix, in the major groove, between the two domains. The rings indicate the $\left(5^{\prime}\right)$ strands which pass through the central channel of the approaching DnaB helicase.

$40 \mathrm{mM}$ Tris, $\mathrm{pH} 7.9,6 \mathrm{mM} \mathrm{MgCl} 2,2 \mathrm{mM}$ spermidine, 10 $\mathrm{mM} \mathrm{NaCl}, 10 \mathrm{mM}$ DTT, and 5\% glycerol).

\section{DISCUSSION}

These results show that surface plasmon resonance can conveniently be used to determine the thermodynamic and kinetic parameters for the binding of Tus to various DNA substrates. Our results cannot be compared directly with previous studies of the Tus-Ter interaction, due to the necessity of using $250 \mathrm{mM} \mathrm{KCl}$ in the binding buffer to bring the equilibrium and rate parameters into a measurable range. Nevertheless, where comparisons are possible, the relative values obtained by different methods are in good agreement. For example, our observation of a 4000-fold increase in the $K_{\mathrm{D}}$ of the complex as a result of the A173T mutation in His $6^{-}$ Tus (Table 3 ) is in good agreement with previously published studies of the effect of the A173T substitution, which reported a 4000 -fold increase in $K_{\mathrm{D}}$ in $50 \mathrm{mM}$ Tris $\cdot \mathrm{HCl}, \mathrm{pH}$ 7.5 , and $200 \mathrm{mM}$ potassium glutamate (19). The Tus complex with $\operatorname{Ter} B$ is not easily dissociated, with a salt concentration of $250 \mathrm{mM}$ being required to increase its $K_{\mathrm{D}}$ to $0.5 \mathrm{nM}$ (Table 3). Extrapolation of the data to $[\mathrm{KCl}]=150 \mathrm{mM}$ (Figure 4B) gives values of about $1 \times 10^{-12} \mathrm{M}$ for $K_{\mathrm{D}}$ and $5 \times 10^{9}$ $\mathrm{M}^{-1} \mathrm{~s}^{-1}$ for the association rate constant $k_{\mathrm{a}}$. The high value for $k_{\mathrm{a}}$ suggests that the rate of the association process would be diffusion limited under these conditions. By way of comparison, Gottleib et al. (9) reported a value for the $K_{\mathrm{D}}$ of $0.34 \times 10^{-12} \mathrm{M}$ and a diffusion-limited association rate constant in $150 \mathrm{mM}$ potasssium glutamate, $\mathrm{pH}$ 7.5. The factor of 3 difference in $K_{\mathrm{D}}$ between results obtained in buffers containing glutamate instead of chloride is likely due to the glutamate ion, which is known to promote binding (30), presumably in this case by failing to increase the dissociation rate as much as does $\mathrm{KCl}$.

Despite knowledge of the crystal structure of the TusTerB complex (18), there are unresolved questions concerning both the mechanism of DNA binding by Tus and how this leads to polar replication fork arrest. Although we concentrate in this work on the former process, the results are likely to have implications for understanding of the latter. The fundamental question in regard to polar replication fork arrest is, how is it that a replisome approaching the TusTerB complex from only one direction (the permissive direction; see Figure 6) actively promotes the release of Tus? The answer will lie in the essential difference between the faces of the DNA-Tus complex that makes one permissive and one nonpermissive for the passage of replisomes. This raises other more specific questions. For example, does Tus interact with other proteins of the E. coli replisome at the replication fork? If so, does it interact only when both, or one or the other, are bound to the DNA? Does Tus engineer a structure in the DNA surrounding the binding site or, conversely, can the replisome engineer a DNA structure that leads to rapid dissociation of Tus? What is the solution structure of the uncomplexed protein and how does it relate to the DNA-bound structure? How dynamic is the bound structure?

Our immediate concern in this work was to examine the roles of particular sequence-specific DNA-binding residues of Tus located outside the core binding domain on the specificity and avidity of DNA binding, anticipating that the results might also comment directly on some of the other more general questions. Detailed kinetic and thermodynamic data, when related to clues derived from the crystal structure, should help to define how dynamic the protein-DNA complex is and what effect this has on anti-helicase activity. Evidence for or against structures engineered by Tus in the DNA or interactions with other replication proteins will contribute to the ongoing debate on the role of these processes in replication arrest, as would determination of the structure of the free protein.

The four amino acid residues of Tus that we examined by mutagenesis are evenly distributed between the geographical extremes of the protein-DNA complex. When the complex is viewed as in Figure 6, R198 is at the top of the C-domain and is largely responsible for holding the $\mathrm{C}$-domain against the Ter site at the nonpermissive (helicase-blocking) end of the complex. Residue K89 is at the top and Q250 is at the bottom of the complex, both in the larger N-domain. A173 is in the center of the complex in the core $\beta$-strand DNAbinding domain.

Substitutions at K89, A173, and Q250 had no significant effect on (nonspecific) Tus binding to oligonucleotides that do not resemble TerB (Table 5). This shows that the effect of these substitutions is limited to the sequence-specific interactions between Tus and TerB, which confirms that in solution the side chains of these residues make sequencespecific contacts with bound TerB DNA, as observed in the crystal structure (18). The effect of each of the K89A, A173T, and Q250A substitutions is to increase $K_{\mathrm{D}}$ of the Tus - TerB complexes by about $2-3$ orders of magnitude (Table 3). This comes about as a result of a greater increase in $k_{\mathrm{d}}$ than decrease in $k_{\mathrm{a}}$. This suggests that these residues, two of which are located in the N-domain of Tus and the other in the core DNA-binding region (Figure 6), may play a greater role in maintaining the complex than in the process of complex formation.

Conversely, the R198A substitution (in the C-domain) has effects that are quite different, and this difference is likely to have significant implications for the role of R198 in fork arrest, as described later. The effect of the mutation is largely on $k_{\mathrm{a}}$, which decreases 80 -fold while $k_{\mathrm{d}}$ increases only 4 -fold. This suggests that R198 is involved in a rate-determining 
step in complex formation. The effect of the modification on the nonspecific interaction is also large (Table 5), with $k_{\mathrm{d}}$ now increased enough to make it unmeasurable. In fact, the effect on nonspecific binding, which presumably reflects electrostatic interaction of R198 with DNA phosphates, accounts for a substantial fraction of the increase in $K_{\mathrm{D}}$ for the interaction with $\operatorname{Ter} B$. Arginine-198 is the only residue modified in this study that has (water-mediated) interactions with the backbone of the Ter DNA in the crystal structure, in addition to its forming specific hydrogen bonds (18) with adjacent adenine and guanine bases [A5 and G6 in the TerB nucleotide numbering system of Coskun-Ari and Hill (33), which will be used throughout this discussion]. Although substitutions of the GC6 base pair in TerB cause only small changes in the ability of wild-type Tus to bind in vitro, they have significant negative effects on the efficiency of replication fork arrest, and GC6 is conserved in all known Ter sites (33).

The weaker binding of Tus to the smaller 14-bp oligonucleotide $14 r$ TerB provides some additional clues about the structure of the complex in solution. The increased $K_{\mathrm{D}}$ suggests that the complex with the $14 r \operatorname{Ter} B$ is lacking a series of interactions that occur with the 21-bp TerB. Modeling of a longer DNA fragment into the crystal structure, which was determined with a similar TerB fragment (a 14-bp TerB with $5^{\prime}$-unpaired thymidines), suggests that postulated interactions between W243 and Q248 and base pairs TA18 to AT21 (33) have been eliminated. The increase in $K_{\mathrm{D}}$ due to the absence of these nucleotides is at least 2-fold smaller than observed for any of the mutant proteins. This is consistent with the relatively small changes in binding free energy seen on substitution of the nucleotides at these positions (33). The results with $14 r \operatorname{Ter} B$ therefore support the existence of the proposed interactions at the bottom of the complex (33) but indicate that they are not major determinants of sequencespecific DNA recognition by Tus.

Having discussed these details, we will now develop a model for the mechanism of the Tus-Ter binding process. It was noted by Kamada et al. in their report of the crystal structure of the Tus-TerB complex (18) that it is not possible for steric reasons for Tus to dissociate from (and, thus, to associate with) $\operatorname{Ter} B$ without undergoing conformational changes. The evidence gathered in this work and reported studies of effects of tus mutations $(18-20)$ and substitution of nucleotides in Ter sites (33-35) on DNA binding and replication fork arrest suggest to us that Tus binding to TerB involves an ordered series of events that involve structural changes in the protein.

Record (30) proposes that the magnitude of the association rate constant and its dependence on salt concentration provide some information about the binding mechanism. A diffusionlimited association rate which has little or no dependence on salt concentration suggests a process that is diffusion controlled; an association rate that is less than the diffusion limit and has little to no dependence on salt concentration suggests that there are orientational restrictions for the collision complex; and an association rate that is less than the diffusion-controlled rate and which shows a significant dependence on salt concentration suggests that intermediates are important after the elementary diffusional collision step (30). For His ${ }_{6}$-Tus binding to TerB in $250 \mathrm{mM} \mathrm{KCl}$, the measured $k_{\mathrm{a}}$ of $1.2 \times 10^{7} \mathrm{M}^{-1} \mathrm{~s}^{-1}$ is lower than the estimated diffusion limit of $10^{9} \mathrm{M}^{-1} \mathrm{~s}^{-1}$ for proteins binding to small DNA molecules (30). This is almost entirely due to a very strong dependence of the association rate on salt concentration (Figure 4B). Given that our DNA ligands comprise only the TerB site, these data suggest that a protein conformational change takes place after Tus first associates with $\operatorname{Ter} B$, when it is presumably bound nonspecifically.

There is no physical datum that compares the structure of Tus when bound nonspecifically with that in the complex with $\operatorname{Ter} B$. There is some evidence for a difference between free Tus and Tus in the latter complex. Comparison of the secondary structure content of Tus predicted by CD spectroscopy (36) with that observed in the crystal structure of the complex suggests that in solution the two helical domains are intact but the interdomain $\beta$-sheets may be disordered. This raises the possibility that the $\beta$-sheets only become structured on DNA binding. This would not be unusual insofar as there are other known examples of DNA-binding proteins where DNA-induced protein folding contributes to the specificity of the interaction $(37,38)$. Moreover, the $\mathrm{C}$-domain in the crystal structure is made up of little more than two antiparallel helices (see Figure 6). We considered the possibility that it might not comprise a stably folded unit in the absence of stabilizing interactions with TerB. However, in NMR experiments with free Tus, we saw no evidence to indicate that large sections of the protein were unusually flexible. ${ }^{2}$

On the basis of the evidence from the specific and nonspecific binding of Tus and the variants to various TerB molecules and the salt dependence of the interaction, we can propose a model zipper-like mechanism for the process of interaction of Tus with $\operatorname{Ter} B$ DNA involving an ordered series of events. The salt dependence of $k_{\mathrm{a}}$ and the observation that Tus can bind nonspecifically to DNA with reasonable affinity makes it reasonable to assume that the first step in binding involves nonspecific interaction between Tus and the DNA, either at $\operatorname{TerB}$ or at other sites on a long DNA molecule. As the R198A mutation has a large effect on nonspecific binding, it seems likely that R198 and some other basic residues play important roles in this process. On long DNA molecules the nonspecifically bound protein would then scan along the DNA, searching for a Ter site $(39,40)$. The specific recognition of the Ter site is then controlled by another series of residues, primarily in the $\mathrm{N}$-domain and including K89 and Q250. The process of specific binding would then ensue first by DNA-directed rearrangement of the interdomain $\beta$-strands that make up the core binding domain and establishment of strong sequence-specific contacts. Among the residues involved here is A173, which makes a very large contribution to the specificity of binding. This step would then be followed by closure of the C-domain about the DNA. During this process, the DNA helix is deformed and bent, as observed in the crystal structure (18).

Like a zipper, the termination activity of the Tus-Ter complex has polarity. A helicase approaching the complex must actively remove Tus from the DNA in order to pass through the Ter site. Removing the protein requires the ordered reversal of some, at least, of the events that took place during binding. While the Tus-Ter complex appears

\footnotetext{
${ }^{2}$ G. Otting, S. E. Brown, and N. E. Dixon, unpublished results.
} 
to be capable of blocking the action of various helicases in in vitro strand separation assays $(7,10-17)$ and RNA polymerase in transcription (32), the block is often inefficient in such assays, and the polarity is often weak. For example, in contrast to the polar block on the progress of the replisome, entrance of RNA polymerase into a Tus-Ter site promotes the dissociation of Tus from the DNA, regardless of the direction from which the polymerase approaches. In this case, the rebinding of Tus on a time scale faster than reinitiation of translocation of the polymerase is required to prevent further transcription, thus making the block a dynamically controlled process (32).

Thus, there are good reasons at the moment for restricting discussion of the basis for polar replication fork arrest to the specific situation for which the termination system evolved, that of E. coli replisomes approaching the TusTer complex from either direction. The replisomal component likely to make first contact with the complex is the hexameric replicative helicase DnaB, whose atomic structure and mechanism of action remain to be elucidated. A lowresolution model of the DnaB hexamer based on cryoelectron microscopy (41) shows that the six subunits are arranged in a ring that has 3-fold symmetry, with a central channel about $30-40 \AA$ in diameter. The DNA (5') strand on which the helicase moves in the $5^{\prime}$ to $3^{\prime}$ direction passes through the channel (marked in Figure 6), while the other ( $\left.3^{\prime}\right)$ strand is excluded (42). By analogy with information derived from the structure of the bacteriophage T7 hexameric helicase (43), actual strand separation by DnaB is likely to occur at the face of the helicase, some distance from the site(s) in the central part of the channel where ATP hydrolysis drives its translocation in the $5^{\prime}$ to $3^{\prime}$ direction on the $5^{\prime}$ strand. The Tus-TerB complex could thus make intimate, but not necessarily specific, contact with the oncoming face of the helicase, but it would be unable to pass through, not only because of its size and shape but also because of the position of the $3^{\prime}$ strand.

It has been noted previously (see Figure 5 of ref 33 , for example) that Tus makes no phosphodiester backbone contacts whatsoever with the first eight residues of the exposed $3^{\prime}$ strand of $\operatorname{Ter} B$ at the permissive end of the complex (18). It seems likely that this strand would progressively and quite easily be displaced from the complex as a result of strand separation by DnaB approaching the permissive face, with consequent disruption of the specific base contacts with residues at the bottom of the $\mathrm{N}$-domain (first W243 and Q248, followed by Q250, Q252, and residues in the core DNA-binding region). Destabilization of the core binding region would then lead to rapid dissociation of Tus. Detailed examination of the crystal structure shows that R288 is unlikely to interact with nucleotides T18, A19, and/or A20 (on the $3^{\prime}$ strand) while they remain base paired but would be well situated to do so following strand separation (31). This raises the intriguing possibility that Tus may have itself evolved to assist the helicase in removing it from the permissive end of the complex.

Residue R198 is likely to have a key role in helicaseblocking when DnaB approaches from the nonpermissive end of the complex. The major interaction of R198 with TerB is a water-mediated ionic interaction with a backbone $5^{\prime}$ phosphate of G6 on the $5^{\prime}$ strand near the top of the complex (Figure 6). In a situation similar to that at the permissive face, there are no ionic interactions with basic residues of Tus with nucleotides on the $3^{\prime}$ strand until the $5^{\prime}$-phosphate of $\mathrm{C} 10$, although $\mathrm{K} 89$ makes specific contact with the base of T8 (and also T9 on the $5^{\prime}$ strand). Nevertheless, the structure is closed in the region surrounding the $3^{\prime}$ strand, so there are more severe steric impediments to helicasedriven displacement of the $3^{\prime}$ strand than there are at the permissive face. This could be alleviated by the opening of the C-domain, but this would require loss of the interaction of DNA with R198. These arguments notwithstanding, the simplest explanation for the fork-blocking activity of the nonpermissive face of the complex is a kinetic one, that the Tus-Ter complex partially enters the channel of the approaching helicase and that this physically prevents the opening of the C-domain, which would in this situation be the first and necessary step in dissociation of the Tus-Ter complex.

This model provides an explanation for the polarity of termination without needing to invoke specific proteinprotein interactions. In this respect, it builds on that advanced by Kamada et al. (18), who proposed that the polarity of the termination results from the inherent asymmetry of the TusTer interaction. While there has been one reference to unpublished results that show a specific protein-protein interaction between Tus and DnaB (44), we have been unable to detect interaction under a variety of conditions in sedimentation velocity experiments using purified DnaB and Tus (in the absence of DNA). ${ }^{3}$ Further work is required to probe the existence of specific interactions that occur only when both (or one or the other) of the proteins are bound to DNA.

Conclusion. These results demonstrate the ease with which the BIACORE instrument can provide a large amount of information on the DNA-binding activity of a protein. The association and dissociation rate constants as well as the equilibrium dissociation constant can be measured simultaneously. The parallel nature of the chip system allows the determination of binding to several different DNA molecules simultaneously, or alternatively, the same DNA molecule can be examined with different surface loadings to improve the quality of the data and check for the presence of experimental artifacts. The salt concentration can be varied to find conditions under which proteins with binding constants differing by as much as 4000-fold can be examined simultaneously. The dependence of the binding on environmental factors such as salt can also provide insight into the thermodynamics of the interaction. However, it is still critical to ensure that the data collected are of a high standard by performing experiments under conditions which prevent common BIACORE artifacts. These include avoiding surface heterogeneity by immobilizing the DNA specifically (e.g., by a biotin label) and minimizing mass transfer artifacts by immobilizing the DNA at low levels, using a high flow rate, and comparing data from at least two different levels of immobilization (21). The determination of $K_{\mathrm{D}}$ by both kinetic and equilibrium methods confirms the model used for data analysis. In comparison to some commonly used methods to study the binding of proteins to DNA, including filter binding assays, footprinting, gel mobility shift assays,

${ }^{3}$ J. A. Wilce, S. E. Brown, C. S. Miles, and N. E. Dixon, unpublished data. 
equilibrium dialysis, calorimetry, chromatography, and spectroscopic techniques such as fluorescence and NMR (45), surface plasmon resonance provides a flexible method which can measure a very wide range of both kinetic and thermodynamic parameters under a variety of solution conditions.

\section{ACKNOWLEDGMENT}

We are grateful to Drs. Peter Kuempel and Nigel Minton for the supply of plasmids and to Dr. Kosuke Morikawa for providing X-ray coordinates of the Tus-TerB complex in advance of their release. We are indebted to Ms. Penny Lilley for expert technical assistance, to Mr. Carl Braybrook for help with ESI-MS measurements, and to the Australian National University Biomolecular Resource Facility for DNA sequence determination.

\section{SUPPORTING INFORMATION AVAILABLE}

One figure showing physical and genetic maps of the T7 promoter vectors pETMCSI, pETMCSII, and pETMCSIII. This material is available free of charge via the Internet at http://pubs.acs.org.

\section{REFERENCES}

1. Hill, T. M., Henson, J. M., and Kuempel, P. L. (1987) Proc. Natl. Acad. Sci. U.S.A. 84, 1754-1758.

2. Hill, T. M., Kopp, B. J., and Kuempel, P. L. (1988) J. Bacteriol. 170, 662-668.

3. Hill, T. M., Tecklenburg, M. L., Pelletier, A. J., and Kuempel, P. L. (1989) Proc. Natl. Acad. Sci. U.S.A. 86, 1593-1597.

4. Kobayashi, T., Hidaka, M., and Horiuchi, T. (1989) EMBO J. 8, 2435-2441.

5. Hidaka, M., Kobayashi, T., Takenaka, S., Takeya, H., and Horiuchi, T. (1989) J. Biol. Chem. 264, 21031-21037.

6. Kuempel, P. L., Pelletier, A. J., and Hill, T. M. (1989) Cell 59, 581-583.

7. Lee, E. H., Kornberg, A., Hidaka, M., Kobayashi, T., and Horiuchi, T. (1989) Proc. Natl. Acad. Sci. U.S.A. 86, 91049108.

8. Wake, R. G., and King, G. F. (1997) Structure 5, 1-5.

9. Gottlieb, P. A., Wu, S., Zhang, X., Tecklenburg, M., Kuempel, P., and Hill, T. M. (1992) J. Biol. Chem. 267, 7434-7443.

10. Hill, T. M., and Marians, K. J. (1990) Proc. Natl. Acad. Sci. U.S.A. 87, 2481-2485.

11. Uzest, M., Ehrlich, S. D., and Michel, B. (1991) J. Bacteriol. 173, 7695-7697.

12. Amin, A. A., and Hurwitz, J. (1992) J. Biol. Chem. 267, $18612-18622$.

13. Khatri, G. S., MacAllister, T., Sista, P. R., and Bastia, D. (1989) Cell 59, 667-674.

14. Bedrosian, C. L., and Bastia, D. (1991) Proc. Natl. Acad. Sci. U.S.A. 88, 2618-2622.

15. Hidaka, M., Kobayashi, T., Ishimi, Y., Seki, M., Enomoto, T., Abdel-Monem, M., and Horiuchi, T. (1992) J. Biol. Chem. 267, 5361-5365.

16. Horiuchi, T., Fujimura, Y., Nishitani, H., Kobayashi, T., and Hidaka, M. (1994) J. Bacteriol. 176, 4656-4663.
17. Sahoo, T., Mohanty, B. K., Lobert, M., Manna, A. C., and Bastia, D. (1995) J. Biol. Chem. 270, 29138-29144.

18. Kamada, K., Horiuchi, T., Ohsumi, K., Shimamoto, N., and Morikawa, K. (1996) Nature 383, 598-603.

19. Skokotas, A., Wrobleski, M., and Hill, T. M. (1994) J. Biol. Chem. 269, 20446-20455.

20. Skokotas, A., Hiasa, H., Marians, K. J., O’Donnell, L., and Hill, T. M. (1995) J. Biol. Chem. 270, 30941-30948.

21. Schuck, P. (1997) Annu. Rev. Biophys. Biomol. Struct. 26, $541-566$.

22. Vasudevan, S. G., Armarego, W. L. F., Shaw, D. C., Lilley, P. E., Dixon, N. E., and Poole, R. K. (1991) Mol. Gen. Genet. 226, 49-58

23. Chambers, S. P., Prior, S. E., Barstow, D. A., and Minton, N. P. (1988) Gene 68, 139-149.

24. Rosenberg, A. H., Lade, B. N., Chui, D.-S., Lin, S.-W., Dunn, J. J., and Studier, F. W. (1987) Gene 56, 125-135.

25. Love, C. A., Lilley, P. E., and Dixon, N. E. (1996) Gene 176, 49-53.

26. Elvin, C. M., Thompson, P. R., Argall, M. E., Hendry, P., Stamford, N. P. J., Lilley, P. E., and Dixon, N. E. (1990) Gene 87, 123-126.

27. Studier, F. W., Rosenberg, A. H., Dunn, J. J., and Dubendorff, J. W. (1990) Methods Enzymol. 185, 60-89.

28. Miles, C. S., Weigelt, J., Stamford, N. P. J., Dammerova, N., Otting, G., and Dixon, N. E. (1997) Biochem. Biophys. Res. Commun. 231, 126-130.

29. Gill, S. C., and von Hippel, P. H. (1989) Anal. Biochem. 182, 319-326.

30. Record, M. T., Jr., Ha, J.-H., and Fisher, M. A. (1991) Methods Enzymol. 208, 291-343.

31. Neylon, D. C. (1999) Ph.D. Thesis, Australian National University.

32. Guajardo, R., and Sousa, R. (1999) Nucleic Acids Res. 27, 2814-2824.

33. Coskun-Ari, F. F., and Hill, T. M. (1997) J. Biol. Chem. 272, $26448-26456$.

34. Duggan, L. J., Hill, T. M., Wu, S., Garrison, K., Zhang, X., and Gottlieb, P. A. (1995) J. Biol. Chem. 270, 28049-28054.

35. Duggan, L. J., Asmann, P. T., Hill, T. M., and Gottlieb, P. A. (1996) Biochemistry 35, 15391-15396.

36. Coskun-Ari, F. F., Skokotas, A., Moe, G. R., and Hill, T. M. (1994) J. Biol. Chem. 269, 4027-4034.

37. Härd, T., and Lundbäck, T. (1996) Biophys. Chem. 62, 121139.

38. Wright, P. E., and Dyson, H. J. (1999) J. Mol. Biol. 293, 321331.

39. Berg, O. G., Winter, R. B., and von Hippel, P. H. (1981) Biochemistry 20, 6929-6948.

40. Shimamoto, N. (1999) J. Biol. Chem. 274, 15293-15296.

41. San Martin, C., Radermacher, M., Wolpensinger, B., Engel, A., Miles, C. S., Dixon, N. E., and Carazo, J.-M. (1998) Structure 6, 501-509.

42. Jezewska, M. J., Rajendran, S., Bujalowska, D., and Bujalowski, W. (1998) J. Biol. Chem. 273, 10515-10529.

43. Sawaya, M. R., Guo, S., Tabor, S., Richardson, C. C., and Ellenberger, T. (1999) Cell 99, 167-177.

44. Manna, A. C., Pai, K. S., Bussiere, D. E., Davies, C., White, S. W., and Bastia, D. (1996) Cell 87, 881-891.

45. Lohman, T. M., and Bujalowski, W. (1991) Methods Enzymol. 208, 258-290.

BI001174W 